\section{Administrative Discretion in} Participatory Processes

\author{
Roberto Falanga \\ Sociology, Instituto de Ciências Sociais, \\ Universidade de Lisboa, \\ Lisbon, Portugal
}

\section{Synonyms}

Bureaucracy; Discretionary power; Institutionalization; New governance; New public management; Public administration; Public officials; Public participation; Public policymaking

\section{Definition}

Administrative discretion in participatory processes refers to the degrees of power exerted by public officials at the margins of formal roles. As participatory processes in policymaking require public officials to intermediate between political representatives and social agents, administrative discretion is a key feature for the (re)configuration of public officials' roles in public administration.

\section{Introduction}

Weber's theoretical model of bureaucracy provided an ideal type of organization for the management of democratic governance in the nineteenth century. The author identifies formal rules and procedures and argues the adoption of impersonal behavior by public officials in order to ensure a clear-cut separation between personal and organizational interests. The autonomy of bureaucracies was supposed to secure stability and continuity of democratic governance against the discontinuity of political cycles. More recently, scholarly debate has focused on bureaucracy as the organizational and normative structure that sustains democratic governance, and upon which public officials can develop fulltime and lifelong careers. Ethical codes of behavior concerning duties and rights of the civil service provided by bureaucracies should secure the fair relationship between governors and those they govern against arbitrary practices in policymaking.

The Weberian ideal type of bureaucracy has been debated by scholars, who have problematized its potentials and limitations. While acknowledging the need for hierarchical distribution of roles in policymaking, the "black box" comprising decision-making has increasingly required further discussion upon matches and mismatches between different levels of political powers, as well as between administrators and political representatives. In addition, the role of external environmental pressures is recognized as a source of potential conflict with the preservation of stable boundaries and roles. Acknowledging both internal and external 
limitations, Selznick (1957) questions the effectiveness of approaching civil service according to merely formal rules, which may rather lead towards forms of "incapacity" of adaption to changing environments. The acknowledgment that public officials relate to each other according to formal rules and beyond has made Gouldner (1959) state that discipline-driven and impersonal rules are likely to reduce the commitment of public officials and, thus, the accomplishment of public administration's goals. This position echoes Merton's argument (1938) upon the "professionalized incapacity" of public officials to exert their functions and the increased difficulty in adapting to environmental changes, as the most probable outcome of Weberian bureaucracy.

While the ways through which public administrations are formally ruled and organized matters, the behavior of administrators, and the development of relationships out of the rigid grids of formal codes requires critical understanding. Multiple schools of thought and administrative reforms in the twentieth century have diversely captured the opportunity to reconfigure the formal division between elected and public officials. During the 1980s and 1990s, the "new public management" school of thought put emphasis on the need for highly professionalized top-level managers in public administration, who were required to ensure loyalty to elected officials (Osborne and Gaebler 1992). Professionalization and political loyalty were argued to radically transform the legally based neutral status of public officials, and the relationship among top-, middle-, and street-level public officials.

New public management-led reforms in public administration aimed at intervening in the enduring struggle, as Weber himself acknowledged, of political and technical expertise in public administration. More recently, scholars have recognized that new public management reforms do not adequately respond to the emerging complexity of different forms of expertise from within and outside public administration, which have considerable influence over effective policymaking. According to Page (2007), not only top-level bureaucrats but all levels of official hold responsibilities that expose them to potential alignments and conflicts with elected officials. The establishment of new networks and partnerships between governmental and nongovernmental agencies and the growth of new connections with associated and nonassociated citizens in participatory processes raise questions about current boundaries of political and administrative powers.

The "new governance" school of thought has shed light on the political output as part of a wider process of negotiation and bargaining with economic and social agents (Rhodes 1996). Against the emphasis on mere instrumental rationality underlying policy agents, there has been broad agreement on the need to render policymaking more open to and adequate for targeted public agents. However, without the reconfiguration of public officials' expertise and roles, from top to street levels, misperceptions and misunderstandings among the agents engaged in decisionmaking may become a major hurdle for the success of participatory processes. More pointedly, the potential conflict emerging between standard bureaucracies and participatory processes requires deeper understanding on the ways public officials contribute to their management within and beyond formal roles.

\section{Understanding the Roles of Public Officials in Participatory Processes}

Scientific literature on the participation of both associated and nonassociated citizens in policymaking processes is longstanding and abundant. The growth of participatory processes worldwide confirms a great diversity of sociopolitical contexts, publics, and policy issues covered by these processes. Furthermore, the adoption of a wide variety of methods, mechanisms, and techniques, such as public hearings, citizen juries, advisory committees, consensus conferences, ballot initiatives, and the like, corroborates the growing importance of this field of study and practice (Gaventa and Barret 2010).

The management of citizen participation proves that standard bureaucracy and recent administrative reforms set up on managerial values are likely to clash with changes brought about by 
participatory processes in public administration (Vigoda 2002). Public administration is the battleground where the design for effective citizen participation in policymaking is conducted, and public officials play a key role in either improving or hindering the execution of participatory processes. As already stated in the 1970s, and confirmed by recent research on the topic, the participation of citizens in policymaking ultimately depends on the type of administrative commitment.

To understand the influence of public officials over the management of effective participatory processes, there is a need to define their formal roles. The wide variability of institutionalization of participatory processes, however, makes this question difficult to answer. Participatory processes can either depend on legal requirements that enforce administrative structures to adopt formal procedures or rely on temporary covenants issued by elected officials (Fung 2015). More often than not, participatory processes are implemented as one-off initiatives to complement standard policymaking, with little guarantee of their continuity in the long run. As stated by Rosenbaum (1976), low enforcement levels may stem from either governmental reluctance, which renders participation politically unrewarding, or administrative resistance against potential public dissensus, which could delay policy implementation.

Varying degrees of institutionalization of participatory processes and institutional designs provide information about the ways in which participatory processes and public officials are placed within the organizational chart, which reflects, to some extent, the ways citizen participation is embraced within the political agenda. Different degrees of institutionalization can have a marked impact on the rulemaking of participation and, therefore, on the definition of the roles of public officials. The variability of institutional designs adopted by participatory processes contributes an additional level of complexity to the understanding of public officials' roles. While, in some cases, participatory processes are managed by administrative networks of departments (or single officials), in other cases, administrative units are created for the exclusive attainment of citizen participation goals, with officials dedicated to the management of participatory processes.

Against this backdrop, scholars are divided over the opportunity to institutionalize participatory processes. According to some thinkers, institutionalizing participatory processes could end up "normalizing" spontaneous practices of civil society and reduce their inner variability. In contrast, Hoppe (2011) argues that "[i]n systems of representative democracy, authorities that initiate deliberative experiments on an ad-hoc basis, but fail to institutionalize relations between deliberative procedures, representative bodies and their normal processes of decision-making, do indeed deserve suspicion." (ibid., 180). The lack of institutionalization may lead to "tick-box" exercises of participatory democracy with narrow scopes of political debate, which is rather transformed into one of mere policy implementation.

\section{At the Margins of Formal Rules: Administrative Discretion in Participatory Processes}

Scholarly debate on the institutionalization of participatory processes does not provide an adequate understanding of the actual functions played by public officials in participatory processes. While the definition of boundaries for policy action helps acknowledge which formal requirements are made by the government to the daily commitment of public officials, the interaction with multiple agents cannot help but open new doors and increase degrees of administrative discretion. Despite efforts for institutionalized rulemaking, policy processes inevitably maintain degrees of discretion, because there is always a gap between the issuing of normative frameworks and the actual behavior in public administrations. Likewise, reforming public administrations to institutionalize participatory processes may lead to organizational inertia or even reluctance (Thompson 1995).

Considering that the (re)configuration of the roles of public officials provides information about the boundaries of their action in 
participatory processes, degrees of discretionary power can be exerted at the margins of formal rules. Lipsky (1980) acknowledges that discretionary power is exerted by street-level bureaucrats whenever problems cannot be reduced to programmatic formats, as well as whenever employees have to make some judgment about people for the application of policies. This power is further nurtured by citizens whenever they believe (and are led to believe) that officials are likely to hold the "key" to their well-being. Consequently, discretionary adjustment of their work to the advantage of their own goals or in favor of citizen interests is likely to lead to diminished transparency of public action.

According to Theodoulou and Kofinis (2004), administrative discretion depends on the enlargement of interpretability of policy goals stemming from little clarity in current policymaking. However, the authors (ibid.) also acknowledge that discretionary power can be of help whenever long-term changes in political and administrative environments are needed. In fact, there is always the potential for public officials to counteract the intentions of elected officials, sometimes accidentally when the legislative process itself is contradictory and there is need for the agency to make sense of the mishmash. In this vein, Lipsky's notion of discretion has been questioned in light of more recent participatory processes. The need to interact with local agents and grasp lay knowledge often provides public officials, and especially street-level bureaucrats, with the exclusive opportunity to improve service delivery at the margins of formal roles. The need to make local knowledge useful for effective policy outputs led Thomas (1995) to propose a ladder, describing degrees of power held by public officials, that goes from autonomous decision-making to broad consultation with the public. However, Rosenbaum (1976) cautions on risks of spurious legitimacy of administrative practices that do not improve disadvantaged groups, which leads to an "abuse" of discretion, and moves beyond paradox to a parody of reform.

Against this backdrop, while there is a view that public officials can be a major hurdle to democratic policymaking whenever moved by personal strategies, and discretionary power is considered a "bias" originating from the failure of formal rules, other scholars view positive contributions from power exerted in the interaction with the public of policymaking. Administrative discretion can be approached as either threatening the formal configuration of administrative roles and functions or as the opportunity to create new connections in the field with social agents. In both cases, more empirical knowledge is needed to broaden the debate on the administrative discretion deployed by public officials at top-, middle-, and street-level.

\section{Conclusion}

Participatory processes challenge standard bureaucracies and previous administrative reforms with new opportunities to reconfigure the roles of public officials. Scholarly debate has focused on administrative discretion by shedding light on the negative and positive sides of it for participatory policymaking. On the one hand, administrative discretion may reproduce biases of unequal distribution of power among sectors of civil society. Out of a transparent definition of principles, mechanisms, and goals of citizen participation, arrangements for social inclusion may rely on nonbinding covenants which have considerable impact on the legitimization of the public agents invited to participate. This type of administrative discretion provides political input over policy processes that are disguised as technical decisions. On the other hand, administrative discretion is a necessary tool for participatory processes inasmuch as it allows for the grasping local knowledge and expertise for effective service delivery. Public officials, from top to street levels, are acknowledged as the gatekeepers for transparent and accountable participatory processes.

While empirical knowledge has been shared on discretionary powers of street-level bureaucrats, however, further research should help to shed light on the ways public officials at all levels contribute to participatory processes at the margins of their formal roles. Towards this aim, it is necessary to take into account the diverse degrees 
of institutionalization that sustain the different institutional designs of participatory processes, which define formal roles and boundaries required for public officials.

\section{Cross-References}

\section{Administrative Discretion}

- Bureaucratic Influence in Policy Formulation

- Citizen Participation in Public Management

- Citizen-Administration Relationship

- Collaborative Public Management

- Co-production and Governance

- Frontline Bureaucrat

- Networks of Governance

- Participatory Budgeting

- Participatory Governance

- Politics and Administration

- Politics and Public Policy

- Public Participation

- Public Value: Bureaucrats Versus Politicians

- Reforms and Governance

\section{References}

Fung A (2015) Putting the public back into governance: the challenges of citizen participation and its future. Public Adm Rev 75(4):513-552

Gaventa J, Barret G (2010) So what differences does it make? Mapping the outcomes of citizen engagement. Working Paper, IDS, vol 347, pp 1-72
Gouldner AW (1959) Organizational analysis. In: Merton RK, Broom L, Cottrell LS (eds) Sociology today: problems and prospects. Harper Torchbook, New York, pp 400-428

Hoppe R (2011) Institutional constraints and practical problems in deliberative and participatory policy making. Policy Polit 39(2):163-186

Lipsky M (1980) Street-level bureaucracy: dilemmas of the individual in public services. Russel Sage Foundation, New York

Merton RK (1938) Social structure and anomie. Am Sociol Rev 3:672-682

Osborne D, Gaebler T (1992) Reinventing government: how the entrepreneurial spirit is transforming the public sector. Addison-Wesley, Reading

Page EC (2007) Middle level bureaucrats: policy, discretion and control. In: Raadschelders JCN, Toonen TAJ, Van der Meer FM (eds) The civil service in the 21 st century. Comparative perspectives. Palgrave Macmillan, New York

Rhodes RAW (1996) The new governance: governing without governance. Polit Stud 44(4):652-667

Rosenbaum WA (1976) The paradoxes of public participation. Adm Soc 8(3):355-383

Selznick P (1957) Leadership in administration. Harper and Row, New York

Theodoulou SZ, Kofinis C (2004) The art of the game: understanding policy making. Thomson Wadsworth, Belmont

Thomas JC (1995) Public participation in public decisions. Jossey-Bass, San Francisco

Thompson J (1995) Participatory approaches in government bureaucracies: facilitating the process of institutional change. World Dev 15(4):1521-1554

Vigoda E (2002) From responsiveness to collaboration: governance, citizens, and the next generation of public administration. Public Adm Rev 62(5):527-540 